\title{
Market Concentration, Risk-taking, and Efficiency of Commercial Banks in Pakistan: An Application of the Two-Stage Double Bootstrap DEA
}

\author{
Ikram Ullah Khan ${ }^{1}$, Sadaqat $\mathrm{Ali}^{2}$, Habib Nawaz Khan ${ }^{3}$
}

\begin{abstract}
Efficiency analysis is a vital part of prudent management practices across the banking industry, yet there is only sparse literature examining bank efficiency, especially in Asian developing countries and using a comprehensive methodology. This study aims to analyze bank efficiency in a South Asian developing country, Pakistan, for the period 2007 to 2014. Borrowing a technique from Simar and Wilson (2007), this study applies two-stage data envelopment analysis (DEA) with double bootstrapping. Our results reveal that private banks are more technically efficient than government banks; conventional commercial banks precede Islamic commercial banks in efficiency, and large banks are more technically efficient than small and medium-size banks. Moreover, the results indicate that market concentration, capital risk, credit risk, and liquidity risk have significant effects on the overall efficiency of banks. This study provides an important opportunity to advance the understanding of bank efficiency, market concentration, and risk complications in developing countries and gives insightful directions to researchers and financial institutions.
\end{abstract}

Keywords: Market concentration; risk-taking; bank efficiency; DEA; double bootstrapping; Pakistan

\section{Introduction}

The global financial system has driven financial institutions towards technological development, innovation, globalization, and deregulation. Banking institutions face multiple challenges to cope with the pressing needs of the contemporary financial system (Stewart, Matousek, \& Nguyen, 2016). This development has transformed the traditional role of banking institutions from raising and utilizing funds to the management of risks and surviving amidst cut-throat competition (Bonin, Hasan, \&

1 Institute of Management Sciences, University of Science and Technology Bannu, KP, Pakistan.

Email:ikram.bnu@gmail.com

2 Institute of Management Sciences, University of Science and Technology Bannu, KP,Pakistan.

3 Department of Economics, University of Science and Technology Bannu, KP, Pakistan.

\begin{tabular}{lll}
\multicolumn{2}{l}{ ARTICLE HISTORY } \\
26 Feb, 18 & Submission Received & 20 Mar,18 First Review \\
\hline 30 Mar, 18 & Revised Version Received & 25 Apr, 18 Second Review \\
\hline 18 May, 18 & Revised Version Received & 30 May, 18 Accepted
\end{tabular}


Wachtel, 2005; Ghosh, 2015; Huang, Chiang, \& Tsai, 2015). In addition, the outbreak of the banking crisis of 2007-2008 confirmed the inseparable relationship of financial institutions and risks while also stimulating banks to review their performance and efficiency (De Haan \& Poghosyan, 2012; Maghyereh \& Awartani, 2014). The current situation amplifies the need for understanding bank efficiency in more subtle detail. Efficiency is thought of as the wise and appropriate allocation of resources, so efficient firms transform their resources into a larger amount of outputs and/or utilize the minimum amount of resources to achieve their target output (Berger \& Hannan, 1998; Berger, Hasan, \& Zhou, 2009; Berger \& Mester, 1997). Efficiency helps enlarge profitability, manages risks, ensures effective use of financial resources, and boosts the provision of satisfactory services. It is considered as a measuring rod for switching to alternative strategies (like restructuring, merger, and acquisition) if the banks in general or a specific group are constantly failing in efficiency (Ghosh, 2015; Stewart et al., 2016).

Emerging economies need more efficient banking systems that are consistent with their economic growth (Mirzaei, Moore, \& Liu, 2013). In any efficiency analysis, the market concentration plays a pivotal role in showing the competitiveness of one bank compared to the whole banking industry. Highly competitive markets compel banks to adopt the latest technologies to improve their efficiency (Berger \& Hannan, 1998; Berger \& Mester, 1997; Hou, Wang, \& Zhang, 2014). Different models have been proposed to analyze the relationship between market concentration and efficiency. For example, the structure conduct performance (SCP), a concept of industrial organization economics, states that the market structure governs conduct which ultimately determines bank performance. SCP assumes a positive relationship between market concentration and bank efficiency (Bain, 1956). The other model refers to the John Hicks "quiet life hypothesis" and assumes market concentration and bank efficiency are negatively associated with each other (Hicks, 1935). The relative market power hypothesis postulates that people usually prefer to use the services of large banks as these banks are perceived as better than smaller banks (Shepherd, 1983). The efficient structure theory states that the efficient banks gain higher market share which eventually leads to high market concentration (Brozen \& Bittlingmayer, 1982; Demsetz, 1973). In the case of perfect competition in the financial market, the banks will strive hard to maintain efficiency and accomplish their targets. Highly competitive markets lead banks to use more sophisticated managerial and technical skills to enhance their efficiency (Hou et al., 2014). On the other side, Bremus (2015) stated that a market structure characterized by less competitive pressures will reduce bank efficiency and will adversely affect the banks' lending rates. Keeping in view the past literature, this study proposes the hypothesis (H1) that market concentration will enhance bank efficiency. 
Bank intermediation involves different types of risks, like credit risk, market risk, liquidity risk and overall risk which ultimately influence banks' performance. Generally, banks are prone to risk-taking which affect their efficiency (Zhang, Jiang, Qu, \& Wang, 2013). Motivated by various banking crisis and disasters, it is incumbent to understand the risk factors by using efficiency studies, especially in developing countries. Past researchers advocated considering risk factors while evaluating the bank's performance (Laeven \& Levine, 2009; Sun \& Chang, 2011). Moreover, the crisis periods such as the Asian banking crisis (1997-1998) and world banking crisis (2007-2008) spurred researchers and bankers to understand the connection between risks and bank efficiency (Hou et al., 2014; Laeven \& Levine, 2009; Soedarmono, Machrouh, \& Tarazi, 2013; Sun \& Chang, 2011; Zhang et al., 2013).

This study seeks to ascertain bank efficiency and its key predictors in a developing country, especially focusing on the period after the world banking crisis of 2007-2008. To the best of authors' knowledge, this is the first study to use a sophisticated DEA methodology to evaluate the technical efficiency of government banks, private banks, and Islamic banks in the context of the South Asian developing economy. Previous studies on bank efficiency overlooked examining the exogenous factors in a comprehensive way (Hou et al., 2014). Filling the gap, the current study uses a two-stage DEA model to calculate the bank efficiency scores and then predict the determinants of the efficiency. As per Ye, Xu, and Fang (2012), the DEA approach is quite feasible to compare the efficiency of decision-making units in the transition economies which are at the developing stage of liberalization. Similarly, considering the environmental factors as predictors of bank efficiency will cover the limitation of DEA which is related to biases in the selection of inputs and outputs (Panayides, Maxoulis, Wang, \& Ng, 2009). The model helps compare the bank efficiencies and determine the crucial factors that affect their efficiency for advancing the understanding of the contemporary banking developments. This study contributes to the extant literature in several ways. First, our study concentrates on a developing economy in the South Asian region, where the efficiency studies are relatively scarce; most previous studies have only focused on developed countries (Matousek, Rughoo, Sarantis, \& Assaf, 2015; Paradi, Yang, \& Zhu, 2011; Wanke, Azad, \& Barros, 2016). The efficiency scores will help researchers compare the government-owned commercial banks (GOCBs) with privately-owned commercial banks (POCBs); small banks with medium and large banks, and Islamic (religious/faith-based) commercial banks (ICBs) with conventional banks (CCBs) in Pakistan. Secondly, the study uses exogenous variables, market concentration, and risk factors, to explore the predictors of bank efficiency in Pakistan's developing economy. Thirdly, taking the worthwhile suggestion of Kauko (2009), the study uses a sophisticated DEA technique with a double bootstrapping procedure, adapted from Simar and Wilson (2007). This technique provides more reliable results in developing 
economies as compared to other methodologies (Barros, Caporale, \& Abreu, 2008; Silva, Tabak, Cajueiro, \& Dias, 2017), like stochastic frontier analysis and ratio analysis (Ye et al., 2012). This study contributes to the DEA literature and will provide further empirical evidence to test the Simar and Wilson (2007) methodology in a new context of Asian and developing countries. Following Laeven and Levine (2009) and Brandao-Marques, Correa, and Sapriza (2018), the study uses control variables (i.e., size, return on assets and GDP growth) to check independently the effect of the stated variables (market concentration and risks) on the overall efficiency of banks.

\subsection{Background of banking system in Pakistan}

Pakistan embraced a policy of economic liberalization in the late 1980s. The State Bank of Pakistan (the central bank of Pakistan) declared many structural and financial reforms in 1988 to reduce the financial burdens and deficits of the economy (Burki \& Niazi, 2010). The reforms were in terms of innovation, privatization, stabilization, and openness to properly address the issues of bank liquidity management, open-policy requirements, and privatization. Responding to public demand, SBP also struggled to introduce interest-free banking (Islamic banking) to meet certain faith-based prerogatives (Khan, 2009). Figure 1 shows the ownership structure of the banking sector of Pakistan during the period 2007-2014. Currently, the banking system of Pakistan consists of Islamic banking and conventional banking. In terms of type and ownership, Pakistan's banking system consists of GOCBs, POCBs, ICBs, foreign banks, and specialized banking institutions. By the end of 2014, the number of commercial banks reached 31 with a total of 11,132 branches throughout the country. The GOCBs numbered five, operating in 2,101 branches. There were 21 private sector banks (including Islamic banks) having 9,020 branches in different corners of Pakistan. The Foreign banks were 5 in number, with only 11 branches, and there were 4 specialized banks with 584 branches in Pakistan. (www.sbp.org.pk).

The banking system in Pakistan consists of both Islamic and conventional banking. Conventional banking works purely on the classical model of the profit motive and interest. Islamic banking in Pakistan is based on the law of Islamic Sharia (Law) in which charging interest (Riba) is prohibited. Islamic banking offers those forms of lending and borrowing where both parties become participants in the profit or loss; customers are considered partners; the rate of return is variable and depends on the profit or loss position. Conventional banking follows a pure financial model, where banks accept the savings of people in return for a fixed interest rate and advances loans to deficit units and charge a higher interest rate (Masudul Alam Choudhury, Abbas, Hammad, Elshahat, \& Azid, 2015; Usmani \& Zubairi, 2002). As of June 30, 2015, there are six Islamic commercial banks in Pakistan, having total assets of Rs 
1817 ( $\$ 18.17$ ) billion, their annual growth rate is 1.3 percent, and their overall share of banking was reported as $9.9 \%$ (www.sbp.org.pk).

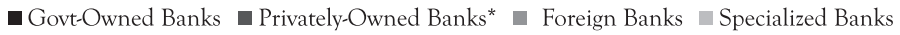

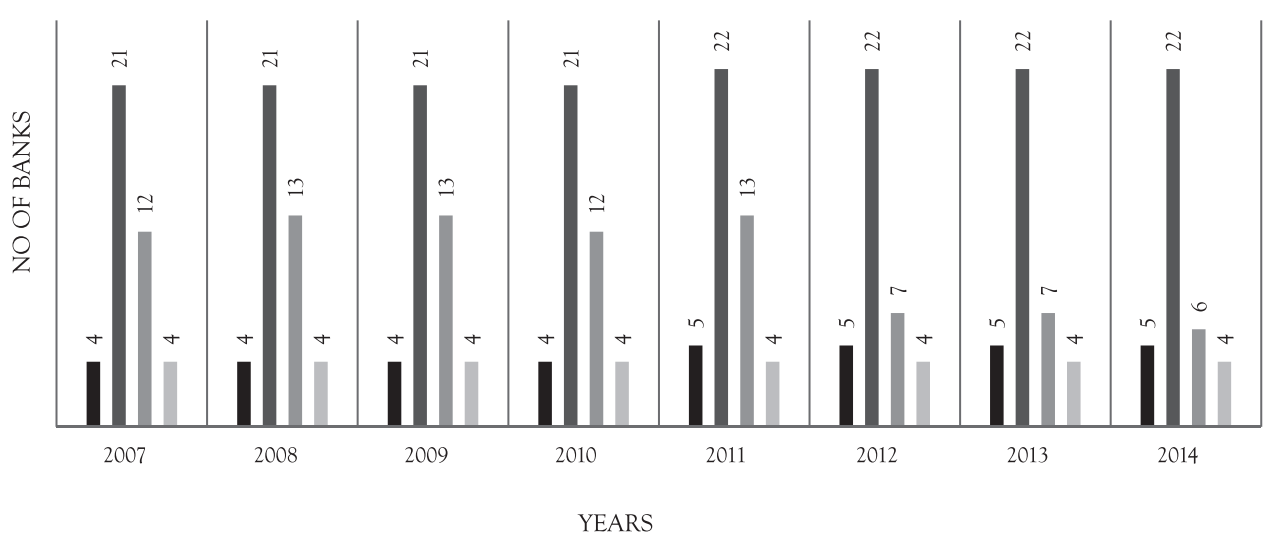

Figure No 1: Ownership Structure of Commercial Banks in Pakistan

Islamic banking emerged at the outset of the $21^{\text {st }}$ century and has a sizable presence in Muslim countries (Usmani \& Zubairi, 2002). Few studies focused on investigating the efficiency of Islamic commercial banks. For example, Hasan and Dridi (2010) analyzed the comparative results of Islamic commercial banks (ICBs) and conventional commercial banks (CCBs) during the crisis period and concluded that the business model and risk management of ICBs performed better than their counterparts (CCBs). The crisis prompted researchers and practitioners to look for alternative models. In this regard, focusing on the Malaysian Islamic banks, Mokhtar, Abdullah, and Alhabshi (2008) found that on average the faith-based banking is progressing in terms of efficiency. They found that the full-fledged Islamic banks are more efficient than the banks having dual banking (Islamic service along with the conventional banking). In their view, the foreign banks having Islamic windows service are better in efficiency than the domestic banks. The CCB outperformed the ICB in Malaysia during the 2003-2007 period due to the managerial efficiency and technological advancement (Ahmad \& Rahim Abdul Rahman, 2012). Using DEA, Sufian (2009) focused on technical and scale efficiency for the Islamic bank performance in Middle Eastern, African, and Asian countries, concluding that the efficiency of Islamic banks is better than their counterpart, conventional banks. This study provides an opportunity to understand and compare the efficiency of ICB with the conventional commercial banks in Pakistan.

There have been few empirical studies focusing on unit level bank efficiency in the south Asian region. Some researchers have investigated the overall efficiency of 
the Pakistani banking system using simplistic models and focusing on the pre-crisis period. For example, Burki and Niazi (2010) analyzed ten years data (1991-2000) to investigate the impact of financial reforms on domestic and foreign banks in Pakistan. They used the maximum likelihood Tobit regression model to analyze the effect of financial reforms on bank efficiency. Soedarmono et al. (2013) researched the impact of financial stability and bank competition in various Asian countries including Pakistan. Another study analyzed the association of market power with revenue diversification and bank stability in South Asian countries, including Pakistan (Nguyen, Skully, \& Perera, 2012). Shafique, Hussain, and Taimoor Hassan (2013) discussed the differences in risk management practices of Islamic financial institutions and conventional financial institutions in Pakistan. Other bank studies in Pakistan include Khan (2014); Aftab, Ahamad, Ullah, and Sheikh (2011); Saeed and Baber Adeeb (2013); Haque and Tariq (2012); Shakil Ahmad, Rashid, and Ehtisham-Ul-Mujeeb (2012). All these studies used simple approaches and did not account for the exogenous variables like market concentration and risk factors that might impact the efficiency of banks. The current study sheds light on this interesting yet under-researched area to understand the efficiency of Pakistani banks in the period characterized by the world banking crisis and the post-crisis period with the advanced methodology of double bootstrapping. The study evaluates the overall efficiency of banks and examines the effects of contextual variables on bank efficiency. The study controls for size, return on assets (ROA), GDP growth, and ownership to portray more reliable results.

\section{Literature Review}

The world banking crisis (2007-2008) disrupted major financial institutions and compelled the institutions to curtail their lending facilities as it uncovered their inefficiencies (Brunnermeier, 2008). The crisis period proved as a focal point for different researchers to understand the complexities of the phenomenon and explore its theoretical and practical implications for practitioners and researchers (Aebi, Sabato, \& Schmid, 2012; Kauko, 2009; Sun \& Chang, 2011; Zhang et al., 2013). The link between risks and bank efficiency has always been a vital phenomenon and especially the world banking crisis warned policymakers to understand and cope with the multiple types of risks. Soedarmono et al. (2013) analyzed selected Asian banks for bank competition, crisis management, and risk taking. They highlighted that a higher market power of banks is associated with an increased level of risk-taking and insolvency risks. Mohsni and Otchere (2014) focused on the risk-taking behavior of banks through using Z-score, volatilities in return on equity and return on assets, and comparisons of NPLs to total loans; they found that the private sector banks face smaller risk than the public sector banks and termed this as an industry-wide phenomenon. Chang (1999) explored the efficiency of Taiwanese major financial 
intermediaries by incorporating risk factors (NPLs, allowance for loan losses, and riskier assets) and concluded that risk has a significant relationship with the bank efficiency. Similarly, Hou et al. (2014) did their research on the risk-taking and bank efficiency of Chinese banks and concluded that Chinese commercial banks need to improve their skills and technical know-how as the market features tough competition. They proved that technical efficiency and risk-taking are positively associated with each other. Based on the past literature, this study believes and proposes that risk has a considerable impact on the efficiency of commercial banks in Pakistan.

Numerous studies have focused on bank efficiency and discussed factors affecting performance and efficiency of banks in the recent past (Aebi et al., 2012; Berger et al., 2009; Berger \& Humphrey, 1997; Hou et al., 2014; Hughes \& Mester, 2013; Kauko, 2009; Kumbhakar \& Wang, 2007; Stewart et al., 2016; Zhang et al., 2013). The association of risks and commercial bank efficiency has been investigated (1993 to 1996) by Altunbas, Liu, Molyneux, and Seth (2000). Analyzing the NPLs and financial capital, they showed that the financial capital has a sizable effect on the efficiency of commercial banks. They indicated that the greater the risk consideration, the smaller the bank's optimal size. The risk and performance of banks in European countries were focused on by Iannotta, Nocera, and Sironi (2007). They analyzed five-year data (1999 to 2004) for 181 large commercial banks and concluded that non-public banks are more profitable than government-owned banks, while the public sector banks are better at handling risk than private banks. They stated that mutual banks are more worthy in terms of quality and risks than the public or private banks.

Laeven and Levine (2009) assessed various theories concerning banks' risk-taking, ownership structure, and bank regulations, concluding that powerful ownership tends to take more risks as compared to weaker. In their empirical research on bank competition, revenue diversification, and bank stability, Soedarmono et al. (2013) concluded that higher market power has an impact on bank risk-taking. Aebi et al. (2012) worked on the risk management, corporate governance and bank performance in the financial crisis period and highlighted the importance of so-called risk management in banks. They concluded that the banks have to improve their service quality and risk management function to be prepared for financial crises. Investigating the determinants of European bank risk, Haq and Heaney (2012) found that the larger banks reveal a higher level of total risk and lower level of credit risks.

\subsection{Data envelopment analysis versus stochastic frontier approach}

Several researchers have used the stochastic frontier approach (SFA) in their empirical research focusing on transition economies (Bonin et al., 2005; Fries \& Taci, 2005; Staikouras, Mamatzakis, \& Koutsomanoli-Filippaki, 2008; Sun \& Chang, 
2011), but SFA requires a specific functional form which may not be suitable for the young banking industry of developing countries (Yao, Han, \& Feng, 2008). The use of DEA is realistic because the SFA requires various assumptions while specifying outputs and inputs, which are usually not clearly known (Zhang, Unruh, \& Wan, 2008). Fewer assumptions are required for DEA and, therefore, it is free from specifying the production function, i.e, there is low chances of misspecification (Davidova \& Latruffe, 2007). Ye et al. (2012) also preferred DEA over SFA and advocated that the use of DEA is more appropriate for the transition economies that are not yet fully mature or liberalized. Rosman, Wahab, and Zainol (2014) investigated the efficiency of Middle Eastern and Asian banks using of DEA and stated that DEA is very suitable in estimating the technical, scale, and overall efficiency of banks in developing countries. DEA is capable of analyzing multiple inputs and multiple outputs for various industries and in various contexts. Moradi-Motlagh and Babacan (2015) substantiated that DEA is a powerful methodology for the benchmarking of efficiencies across a range of different industries, sectors, portfolios, nations, and other economic entities. An important advantage is that DEA does not require any specific functions and therefore it is preferred by researchers (Hou et al., 2014; Lu, Chiu, Shyu, \& Lee, 2013; Moradi-Motlagh \& Babacan, 2015; Sufian \& Habibullah, 2011).

\subsection{Two-stage DEA with double bootstrapping}

In the recent past, several researchers have used the methodology of DEA double bootstrapping while analyzing the efficiency of financial institutions. The two-stage DEA incorporates the stochastic factor that was missing in DEA and hence it represents a more favorable approach in the context of emerging economies, covering the environmental factors (Odeck, 2007). Stewart et al. (2016) assessed bank efficiency in Vietnam by applying the double bootstrap procedure adopted from (Simar \& Wilson, 2007). They compared the efficiency of different types of banks during the 11-year period from 1999 to 2009. Wanke, Barros, and Emrouznejad (2016) used fuzzy DEA with double bootstrapping and the truncated regression model. They worked on the case of Mozambican banks and identified the most relevant contextual variables affecting efficiency. Wijesiri, Viganò, and Meoli (2015) examined the technical efficiency of 36 microfinance institutions in Sri Lanka using the double bootstrapping procedure. They constructed two models and claimed that their major contribution is the use of an innovative two-stage double bootstrap DEA approach. Moradi-Motlagh and Babacan (2015) measured the technical and scale efficiencies of major Australian and some regional banks before, during, and after the global banking crisis. Using the bootstrap DEA approach, they determined that only small banks can enhance their efficiency through possible future mergers. Another study ascertained bank efficiency in China by employing the two-stage DEA model and accounted for the 
market structure and risk-taking factors (Hou et al., 2014). That study employed a twostage DEA model with double bootstrapping and used a truncated regression model in the second stage. Alexander, Haug, and Jaforullah (2010) analyzed the efficiency of secondary schools in New Zealand by using the double bootstrap procedure from Simar and Wilson (2007). They stated that this procedure permits valid inference even if there is an unknown serial correlation in the efficiency scores. The double bootstrapping procedure is able to improve statistical efficiency in the second-stage (Simar \& Wilson, 2007). Jebali, Essid, and Khraief (2017) used the double bootstrap procedure where they clarified that the procedure is appropriate for both bias and serial correlation of (banks') efficiency scores. Similarly, Banya and Biekpe (2018) recently employed the Simar and Wilson (2007) truncated bootstrapping methodology to ascertain the determinants of banks' efficiency in 10 African countries. Keeping in view the pluses of the method, the current paper employs the double bootstrapping procedure because of its valid inference capability, which is especially important when there unknown and complex serial correlations among the estimated efficiencies.

Table 1: Definition of Variables, Inputs, and Outputs

\begin{tabular}{|c|c|}
\hline A. & \\
\hline 1. & $\begin{array}{l}\text { Market Concentration: This term refers to the distribution of production within the whole } \\
\text { industry. It also serves as a measure of competition within an industry and is determined by the } \\
\text { Herfindahl-Hirschman Index (HHI) (Hou et al., 2014). }\end{array}$ \\
\hline 2. & $\begin{array}{l}\text { Capital Risk (CapR): Denoted by the ratio of equity to total assets, the CapR refers to the } \\
\text { bank's concern that it may lose the principal amount invested (Zhang et al., 2013). }\end{array}$ \\
\hline 3. & $\begin{array}{l}\text { Credit Risk (CrR): The risk of loss due to the debtors' inability to repay. It is calculated as the } \\
\text { ratio of non-performing loans to total loans/advances (Zhang et al., 2013). }\end{array}$ \\
\hline 4. & $\begin{array}{l}\text { Liquidity Risk (LqR): Represented by the ratio of total loans to total deposits, the LqR is com- } \\
\text { monly known as the bank's ability to meet its short-term obligations without facing unnecessary } \\
\text { loss(es) (Fiordelisi, Marques-Ibanez, \& Molyneux, 2011). }\end{array}$ \\
\hline 5. & $\begin{array}{l}\text { Overall Risk (OvR): The OvR is proxied by loan loss provision to non-performing loans (Fior- } \\
\text { delisi et al., 2011) }\end{array}$ \\
\hline B. & \\
\hline 1. & $\begin{array}{r}\text { Total Deposits: This refers to the total funds } \\
\text { savings accounts, P\&L ac }\end{array}$ \\
\hline 2. & Fixed Assets: All the long-term assets of the bank. \\
\hline 3. & Employees: An ir \\
\hline 4. & Administrative Expenses: All the general and admi \\
\hline C. & \\
\hline 1. & $\begin{array}{l}\text { Total Loans: refers to all the net loans and advances to the customers (net of provision for } \\
\text { non-performing loans). }\end{array}$ \\
\hline 2. & $\begin{array}{l}\text { Interest/Profit: This term refers to the net interest income for conventional banks and profit/ } \\
\text { markup for Islamic banks. }\end{array}$ \\
\hline 3. & $\begin{array}{l}\text { Investments: This refers to the bank's investments in government bonds, debentures, treasury } \\
\text { securities, and shares of other entities. }\end{array}$ \\
\hline 4. & butput \\
\hline
\end{tabular}




\section{Research Methodology}

\subsection{Input and output specification}

How to specify the inputs and outputs of decision-making units (DMUs) is always debatable. The input-output specification is usually based on the underlying approach. For example, the production approach portrays banks as producers of loans from the deposits of individuals and corporations. The intermediation approach considers banks as an intermediary between depositors and lenders. Being focused on a developing economy, the current study assumes the intermediation approach, where banks are considered as middlemen between saving units and borrowing units. In this context, the bank's main function is to facilitate depositors by taking their savings and facilitate borrowers by providing loans and credits. The study uses deposits, fixed assets, number of employees, and general and administrative expenses as input variables while total loans, investments, interest/profit, and other incomes are the output variables (Berger \& Hannan, 1998; Berger \& Humphrey, 1997; Luo, Yao, Chen, \& Wang, 2011; Sufian, 2009; Sufian \& Habibullah, 2011; Sun \& Chang, 2011). The explanatory variable market concentration is represented by the Herfindahl-Hirschman Index (HHI) in deposits (Berger \& Humphrey, 1997; Fu \& Heffernan, 2009; Pan, 2005), while the study evaluates four types of risks: capital risk, credit risk, liquidity risks, and overall risk (Zhang et al., 2013). We further consider bank size, GDP growth, and return on equity (ROE) as control variables because they may influence the efficiency of banks (Laeven \& Levine, 2009; Lensink, Meesters, \& Naaborg, 2008).

\subsection{Data envelopment analysis}

The study uses two-stage DEA with the double bootstrapping procedure. DEA is a mathematical programming approach where first certain frontiers are established and then the efficiency is evaluated in comparison to those pre-established frontiers. The comparison of DMUs through using DEA is more convenient and meaningful in benchmarking when there are a sufficient number of inputs and outputs (Cook, Tone, \& Zhu, 2014). Laying the foundation of DEA in 1978, Charnes, Cooper, and Rhodes (1978) stated that it provides better results when DMUs are evaluated and compared with each other. The CCR (Charnes, Cooper, and Rhodes) model assumes constant returns to scale, where inputs and outputs are changed in the same proportion.

Input-oriented CCR model

$$
\begin{array}{ll}
\min & \theta_{o} \\
\text { s.t. } & \sum_{i=1}^{n} \lambda_{j} x_{i j} \leq x_{i o}, \forall i=1, \ldots, m \\
& \sum_{j=1}^{\lambda_{j}} \lambda_{j} y_{r j} \geq 0, \forall j=\theta_{o} y_{r o}, \forall r=1, \ldots, \ldots, n
\end{array}
$$

Output-oriented CCR model $\min \theta_{o}$

$$
\begin{array}{ll}
\text { s.t. } & \sum_{i=1}^{n} \lambda_{j} x_{i j} \leq \theta_{o} x_{i o}, \forall i=1, \ldots, m \\
& \sum_{j=1}^{h=1} \lambda_{j} y_{r j} \geq y_{r o}, \forall r=1, \ldots, S \\
& \lambda_{j} \geq 0, \forall j=1, \ldots, n
\end{array}
$$


The CCR model is usually used to calculate the overall efficiency (OE). The second model introduced by Banker, Charnes, and Cooper (1984) is known as the BCC model, which calculates the technical efficiency (TE).

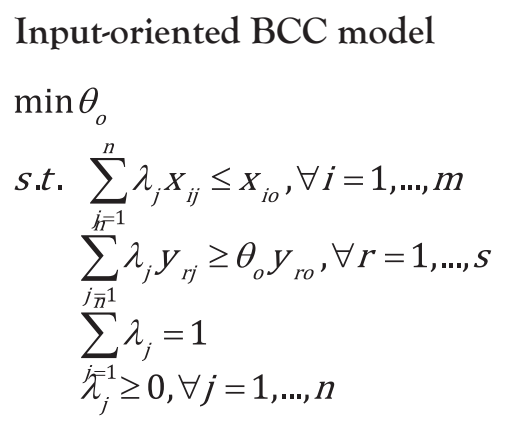

$$
\begin{aligned}
& \text { Output-oriented BCC model } \\
& \min \theta_{o} \\
& \text { s.t. } \sum_{i=1}^{n} \lambda_{j} X_{i j} \leq \theta_{o} X_{i o}, \forall i=1, \ldots, m \\
& \sum_{j_{\bar{n} 1} 1}^{h_{n} 1} \lambda_{j} y_{r j} \geq y_{r o}, \forall r=1, \ldots, s \\
& \begin{array}{l}
\sum_{j=1}^{n_{n}^{n}} \lambda_{j}=1 \\
\lambda_{j} \geq 0, \forall j=1, \ldots, n
\end{array}
\end{aligned}
$$

The ratio between OE and TE is known as scale efficiency (SE). This model supposes variable returns to scale so the proportions of inputs and outputs are variable (decreasing returns to scale or increasing to scale). Later on, various extensions were made to the original models. DEA results are preferred to previous methods because it does not impose any functional form on data, especially in the case of DMUs with different ownership structure and size. A large number of studies using DEA model take into account quantitative data to find the technical efficiency.

Ye et al. (2012) stated that DEA is suitable for those financial decision-making units where the financial market is not well developed because the DEA needs fewer assumptions. Rosman et al. (2014) also asserted that DEA is very suitable for estimating the technical, scale, and overall efficiency of banks in the developing countries. It is rightly capable of taking and analyzing the multiple inputs and outputs for various firms. Bank efficiency can be analyzed through several methods, for example, ratios to evaluate the banks or branch performance (Beccalli, Casu, \& Girardone, 2006; Berger \& Humphrey, 1997). Some studies used the regression analysis but again there are issues due to the multiple inputs and outputs as well as issues in the comparative analysis of DMUs (Yang \& Liu, 2012). Iqbal and Molyneux (2005) viewed that evaluating efficiency with a frontier approach is better than the ratio analysis because the frontier analysis encompasses all the inputs and outputs and other relevant factors.

\subsection{Double bootstrap procedure}

The study uses a two-stage methodology to arrive at the results. First, applying DEA, the study calculates the OE of commercial banks under both BCC and CCR models. The use of alternative models will give a more detailed picture by handling both constant returns to scale and variable returns to scale (Stewart et al., 2016). In 
the second stage, following (Hou et al., 2014; Wijesiri et al., 2015), the efficiency scores are regressed for the contextual variables using the Simar and Wilson (2007) methodology. The second stage regression is vital for getting meaningful results, as the truncated regression and double bootstrapping will solve the issue of errors and random noise (Worthington, 2004).

In this two-stage DEA model, the second stage is crucial because the efficiency scores have problems of serial correlation. In estimating the effect of contextual variables in the two-stage DEA model, some researchers have used the Tobit regression model (Ariss, 2010), Malmquist Index (Lin, Hsu, \& Hsiao, 2007), and ordinary least squares (OLS) (Banker \& Natarajan, 2008) but the second stage regression can be handled well by using a double bootstrap and truncated regression model ( $\mathrm{Li}$, Liu, Liu, \& Chiu, 2017; Simar \& Wilson, 2007; Stewart et al., 2016). The second stage assumes that the data is generated through some data generating process. We used the software "R" for getting Algorithm 1 and Algorithm 2 to correctly estimate our results. This study applies both Algorithm 1 and Algorithm 2 to obtain more comprehensive results because Simar and Wilson (2007) stated that Algorithm 2 gets better results than Algorithm 1. The double bootstrap confidence intervals are bias-corrected as compared to the conventional confidence intervals under normal approximation. Table 2 shows the steps in the bootstrapping procedure.

Table 2: Double bootstrap procedure

\begin{tabular}{|c|}
\hline Algorithm 1 \\
\hline $\begin{array}{l}\text { Step 1: Using original data of outputs, } Y_{j} \text {, and inputs, } \chi_{j}, j=1, \ldots, n \text { (that are all positive) compute } \\
\text { DEA efficiency scores } \delta_{j} .\end{array}$ \\
\hline $\begin{array}{l}\text { Step 2: Use the method of maximum likelihood to obtain an estimate } \hat{\beta} \text { of } \beta \text { as well as an estimate } \\
\text { in the truncated regression of } \hat{\delta}_{j} \text { on } Z_{j} \text { (Eq. (3)) using } \mathrm{m}<\mathrm{n} \text { observations where } \hat{\delta}_{j} \geq 1 \text {. }\end{array}$ \\
\hline Eq. (3)): $\hat{\delta}_{j}=\boldsymbol{\beta}^{\prime} \mathbf{z}_{j}+\varepsilon_{j}$ \\
\hline $\begin{array}{l}\text { Step 3: Loop over the next three steps }[3.1]-[3.3] 2000 \text { times to obtain a set of bootstrap estimates } \\
\qquad A=\left(\left(\hat{\beta}^{*}, \hat{\sigma}_{\varepsilon}^{*}\right)_{b}\right)_{b=1}^{2000}\end{array}$ \\
\hline [3.1] For each $\mathrm{j}=1 \ldots, \mathrm{n}$, draw $\varepsilon_{j}$ from the $N\left(0, \hat{\sigma}_{\varepsilon}^{2}\right)$ distribution with left-truncation at $\left(1-\mathrm{z}_{j} \beta\right)$. \\
\hline [3.2] Again for each $\mathrm{j}=1 \ldots \mathrm{n}$, compute $\delta_{j}^{*}=\mathrm{z}_{j} \hat{\beta}_{j}+\varepsilon_{j}$. \\
\hline $\begin{array}{l}\text { [3.3] Use the maximum likelihood method to estimate the truncated regression of } \hat{\delta}_{j}^{*} \text { on } z_{j} \text {, yielding } \\
\text { estimates }\left(\hat{\beta}^{*}, \hat{\sigma}_{\varepsilon}^{*}\right) .\end{array}$ \\
\hline $\begin{array}{l}\text { Step 4: Use the bootstrap values in A (step } 3 \text { ) and the original estimates } \hat{\beta}, \hat{\sigma}_{s} \text { to construct estimated } \\
\text { confidence intervals for each element of } \beta \text { and for } \sigma_{\varepsilon} \text {. }\end{array}$ \\
\hline
\end{tabular}




\begin{tabular}{|} 
Algorithm 2 \\
\hline Step 1: Using original data of outputs, $\mathrm{y}_{\mathrm{j}}$, and inputs, $\mathrm{X}_{\mathrm{j}}, \mathrm{j}=1, \ldots \mathrm{n}$ (that are all positive) compute \\
DEA efficiency scores $\delta_{j}$.
\end{tabular}

It is worth mentioning that the study takes account of five contextual variables (one for market concentration and four for risks) after a thorough study of previous literature. The market concentration is measured by the Herfindahl-Hirschman Index (HHI) and the four risk factors are: capital risk, credit risk, liquidity risk, and overall risk (see details in Table 1).

Regression model of the study is given below:

$\delta_{j}=\mathrm{z}_{j} \beta+\varepsilon_{j}$

$\delta_{j, t}=\beta_{1} \mathrm{HHI}_{j, t}+\beta_{2} \mathrm{CapR}_{j, t}+\beta_{3} \mathrm{CrR}_{j, t}+\beta_{4} \mathrm{LqR}_{j, t}+\beta_{2} \mathrm{OvR}_{j, t}+\varepsilon_{j}$

The study also measures several control variables to keep them constant and check effects of market concentration and risk factors accurately. The control variables are bank size, ROE, ownership, and GDP Growth. The descriptive statistics of all the variables are presented in Table 3 . 


\subsection{Data collection}

This study uses the data of 27 commercial banks in Pakistan for an 8-year period ranging from 2007 to 2014 . The period was chosen to take into account the world banking crisis period of 2007-2008 and the post-crisis period, which will help us understand the dynamics of the efficiency after the crisis. This period is also interesting due to the inclusion of Islamic Banking (faith-based banking) as the period contains the time of emergence of Islamic banking in Pakistan.

This research work used secondary data for the analysis which were collected from State Bank of Pakistan publications, official websites of the respective banks, and from "BankScope". The GDP growth rates have been collected from the international financial statistics published by International Monetary Fund and World Bank data sources.

\section{Empirical Results and Discussion}

\subsection{Descri ptive statistics}

Table 3 shows descriptive statistics for all the inputs, outputs, independent variables, and predicted variables as well as control variables. More specifically, the table shows the minimum values, maximum values, mean, and standard deviation of all the identified variables. We have 216 bank-year observations for the 27 commercial banks operating in Pakistan.

Table 3: Descriptive Statistics

\begin{tabular}{|c|c|c|c|c|}
\hline & Minimum & Maximum & Mean & St.Dev \\
\hline Deposits * $^{*}$ & 2.889 & 1524.5 & 227.4 & 2.8 \\
\hline Fixed Assets * $^{*}$ & 1.487 & 345.7 & 7.6 & 0.9 \\
\hline Employees (No) $^{4}$ & 126.0 & 5103 & 5103 & 4.7 \\
\hline G \& Admn. Exp * $^{*}$ & 1.656 & 41.3 & 7.4 & 0.8 \\
\hline Total Loans* $^{*}$ & 2.622 & 658.7 & 127.3 & 1.4 \\
\hline Interest $^{*}$ & 1.294 & 69.1 & 10.8 & 1.4 \\
\hline Investment $^{*}$ & 1.319 & 924.3 & 104.0 & 1.4 \\
\hline Other Income $^{*}$ & 0.088 & 314.0 & 466.0 & 0.6 \\
\hline HHI & 0.0008 & 0.174 & 0.037 & 0.04 \\
\hline Capital Risk & -0.031 & 0.533 & 0.112 & 0.08 \\
\hline Credit Risk & 0.0002 & 0.516 & 0.124 & 0.10 \\
\hline
\end{tabular}




\begin{tabular}{|c|c|c|c|c|}
\hline Liquidity Risk & 0.309 & 1.290 & 0.661 & 0.17 \\
\hline Overall Risk & 0.072 & 1.644 & 0.745 & 0.27 \\
\hline Size & 15.74 & 21.35 & 18.840 & 1.26 \\
\hline ROA & -0.071 & 0.037 & 0.003 & 0.02 \\
\hline GDP Growth & 0.026 & 0.058 & 0.058 & 0.01 \\
\hline Ownership & 1 & 2 & 1.83 & 0.45 \\
\hline
\end{tabular}

${ }^{4}$ Number of employees are in thousands

*= Pak rupees (billion); G \& Admn. Exp = general and administrative expenses; $\mathrm{HHI}=$ Herfindahl Hirschman index; ROA= Return on equity

\subsection{Efficiency results}

The study discovers the efficiency scores of 27 banks following both Banker, Charnes, and Cooper (BCC) and Charnes, Cooper, and Rhodes (CCR) models in the first stage. The paper uses an output-oriented model for its efficiency analysis because the banking sector of Pakistan, like other Asian developing countries, is more inclined to increase its outputs in the form of advances and incomes (Despotis, 2005). Table 4 shows the mean technical efficiency of commercial banks under both the BCC and CCR models.

Table 4: Average Efficiency Scores of Banks in Pakistan

\begin{tabular}{|c|c|c|c|c|}
\hline & Banks & DEA-CCR & DEA-BCC & DEA Scale-Index \\
\hline 1 & National Bank of Pakistan & 0.87 & 1.00 & 0.87 \\
\hline 2 & First Women Bank Limited & 0.82 & 0.82 & 1.00 \\
\hline 3 & Bank of Punjab & 0.86 & 0.95 & 0.91 \\
\hline 4 & Bank of Khyber & 0.80 & 0.81 & 0.99 \\
\hline 5 & Sindh Bank Limited & 0.92 & 0.92 & 1.00 \\
\hline 6 & Meezan Bank Limited & 0.70 & 0.75 & 0.93 \\
\hline 7 & Dubai Islamic Bank Pakistan & 0.72 & 0.77 & 0.94 \\
\hline 8 & Bank Islami Pakistan Limited & 0.60 & 0.62 & 0.97 \\
\hline 9 & Albaraka Bank Pakistan & 0.61 & 0.65 & 0.94 \\
\hline 10 & Burj Bank Limited & 0.74 & 0.75 & 0.99 \\
\hline 11 & Faysal Bank Limited & 0.86 & 0.96 & 0.90 \\
\hline 12 & Silk Bank Limited & 0.69 & 0.83 & 0.83 \\
\hline 13 & Allied Bank Limited & 0.83 & 1.00 & 0.83 \\
\hline 14 & Habib Bank Limited & 1.00 & 1.00 & 1.00 \\
\hline
\end{tabular}




\begin{tabular}{|c|c|c|c|c|}
\hline 15 & Sonery Bank Limited & 0.78 & 0.82 & 0.95 \\
\hline 16 & Askary Bank Limited & 0.70 & 0.83 & 0.84 \\
\hline 17 & KASB Bank Limited & 0.61 & 0.67 & 0.91 \\
\hline 18 & Standard Chartered Bank Limited & 1.00 & 1.00 & 1.00 \\
\hline 19 & Bank Al-Habib Limited & 0.79 & 0.89 & 0.89 \\
\hline 20 & SAMBA Bank Limited & 0.72 & 0.75 & 0.96 \\
\hline 21 & Summit Bank Limited & 0.76 & 0.79 & 0.96 \\
\hline 22 & Bank Alfalah Limited & 0.67 & 0.82 & 0.82 \\
\hline 23 & United Bank Limited & 0.89 & 0.97 & 0.92 \\
\hline 24 & Habib Metropolitan Bank Limited & 1.00 & 1.00 & 1.00 \\
\hline 25 & JS Bank Limited & 0.59 & 0.64 & 0.92 \\
\hline 26 & Muslim Commercial Bank Limited & 1.00 & 1.00 & 1.00 \\
\hline 27 & NIB Bank Limited & 0.91 & 0.92 & 0.99 \\
\hline
\end{tabular}

Source: Authors' Computations through DEA-Solver and Mat-lab

The above table tells that the efficiency scores of privately owned banks are equal to 1 (lying on the efficiency frontier), indicating more technical efficiency than government-owned banks. The efficiency results clarify that the private banks in Pakistan pay more attention to increasing and managing their outputs diligently, as also found by (Bonin et al., 2005). The technical efficiency (TE) of conventional banks (e.g., nearer to 1) supersedes the TE of Islamic banks which has variations in the scores and are lesser than the overall scores of conventional banks. Among the government-owned banks, the National Bank of Pakistan has outstanding performance (i.e., efficiency scores are maximum through the period), especially using the BCC model, evidencing the fact that the bank was quite efficient throughout the stated period. Moreover, the DEA-efficiency scores highlight that the five Islamic Banks were lagging behind in terms of efficiency level and the large banks were more efficient than the small and medium-size banks. One of the reasons is that the larger the bank size, the better the efficiency because of the economies of scale and reduced per unit cost. More specifically, Table 4 represents that the large private banks (Allied Bank Limited, Habib Bank Limited, Standard Chartered Bank Limited, Habib Metropolitan Bank Limited, and Muslim Commercial Bank) were on the efficient frontier assuming constant returns to scale (BCC model) and four of these (Habib Bank Limited, Standard Chartered Bank Limited, Habib Metropolitan Bank Limited, and Muslim Commercial Bank) were the only banks found efficient using the CCR model. The efficiency estimates show that the TE of commercial banks dropped due to the banking crisis. Figure 2 depicts the overall banking efficiency of commercial banks in Pakistan from 2007 to 2014. 


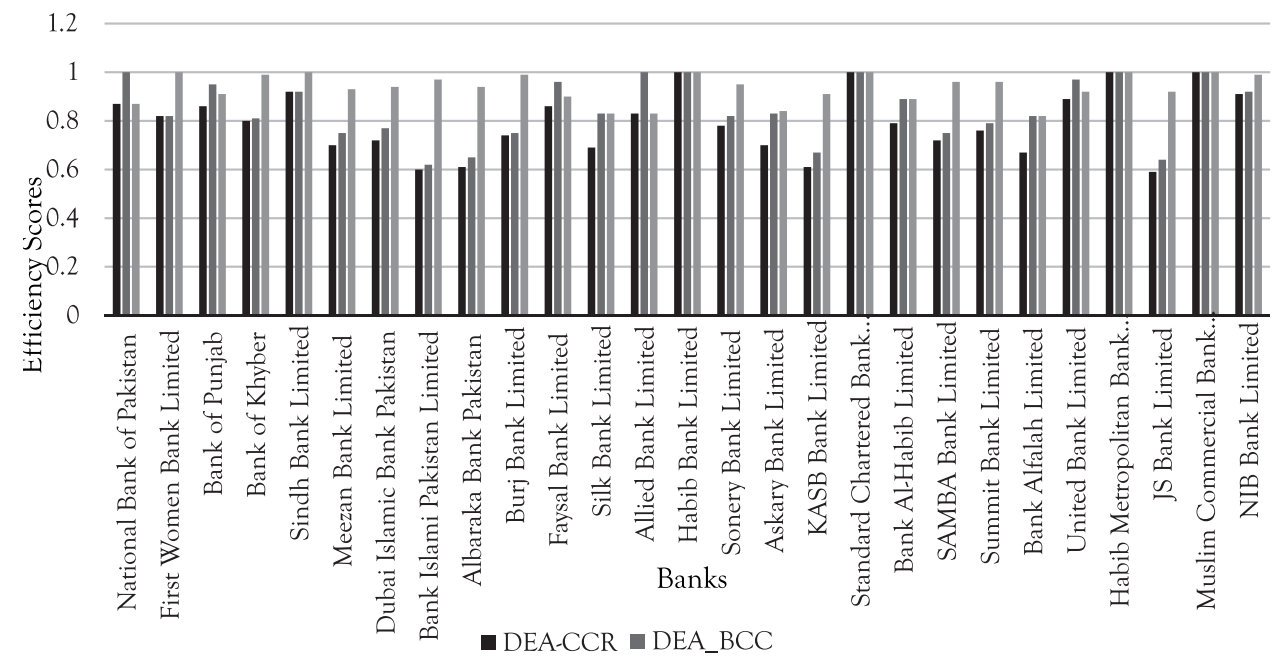

Figure 2: Average Efficiency Scores of Pakistani Banks (2007-2014)

\subsection{Truncated regression}

The second stage analysis requires truncated regression in the double bootstrap procedure (Simar $\&$ Wilson, 2007) because the truncated regression is more feasible where the data is not fully representative of the entire population. In the double bootstrapping procedure, truncated regression is more appropriate than other censored regressions (Wijesiri et al., 2015). Sathye and Sathye (2017) also suggested using truncated regression. Table 5 represents the regression results (Algorithm 1) for the coefficients as well as standard errors of all variables under the CCR model and BCC model. The tables also represent the t-values and $\mathrm{p}$-values of the independent variables (HHI, capital risk, credit risk, liquidity risk, and total risk) and control variables (size, ROA, and GDP growth). The confidence intervals are also given at the end of Table 5 for Algorithm 1 under both CCR and BCC model. Our results show that HHI has a negative but significant relationship with bank efficiency under both CCR and BCC models. Similarly, the results indicate that liquidity risk and overall risk have significant impacts on the efficiency of banks.

Table 6 (Algorithm 2) shows the coefficients, standard errors and significance level under both CCR model and BCC model. The table data indicates that capital risk, liquidity risk, and overall risk are significantly related to efficiency. The confidence intervals for each variables are given at the end of Table 6 for Algorithm 2 under both CCR and BCC model. The result of HHI is negative but significant, showing that the higher the concentration, the lower the bank efficiency. The findings are consistent with the results of (Abbasoğlu, Aysan, \& Gunes, 2007). The liquidity and overall risk are negative but significant indicating that increase in these risks will cause reduction 
Table 5: Regression Model (Algorithm1)

\begin{tabular}{|c|c|c|c|c|c|c|}
\hline & \multicolumn{3}{|c|}{ CCR } & \multicolumn{3}{|c|}{$\mathrm{BCC}$} \\
\hline & Coefficients & $t$-value & $\operatorname{Pr}(>|t|)$ & Coefficients & $\mathrm{t}$-value & $\operatorname{Pr}(>|t|)$ \\
\hline \multirow[t]{2}{*}{ HHI } & -6.642 & \multirow[t]{2}{*}{-4.927} & \multirow[t]{2}{*}{$0.000^{* * *}$} & -9.531 & \multirow[t]{2}{*}{-5.748} & \multirow[t]{2}{*}{$0.000^{* * *}$} \\
\hline & (1.348) & & & $(1.780)$ & & \\
\hline \multirow[t]{2}{*}{ CapRsk } & 0.569 & \multirow[t]{2}{*}{1.418} & \multirow[t]{2}{*}{0.156} & 0.637 & \multirow[t]{2}{*}{1.622} & \multirow[t]{2}{*}{0.105} \\
\hline & $(0.401)$ & & & $(0.393)$ & & \\
\hline \multirow[t]{2}{*}{ CrRsk } & -0.305 & \multirow[t]{2}{*}{-0.814} & \multirow[t]{2}{*}{0.415} & 0.126 & \multirow[t]{2}{*}{0.360} & \multirow[t]{2}{*}{0.719} \\
\hline & $(0.374)$ & & & $(0.350)$ & & \\
\hline \multirow[t]{2}{*}{ LiqRsk } & -1.733 & \multirow[t]{2}{*}{-6.724} & \multirow[t]{2}{*}{$0.000^{* * *}$} & -1.979 & \multirow[t]{2}{*}{-7.349} & \multirow[t]{2}{*}{$0.000^{* * *}$} \\
\hline & $(0.258)$ & & & $(0.269)$ & & \\
\hline \multirow[t]{2}{*}{ OvRsk } & -0.377 & \multirow[t]{2}{*}{-3.266} & \multirow[t]{2}{*}{0.001 ** } & -0.261 & \multirow[t]{2}{*}{-2.320} & \multirow{2}{*}{$0.020^{*}$} \\
\hline & $(0.116)$ & & & $(0.113)$ & & \\
\hline \multirow[t]{2}{*}{ Size } & 0.133 & \multirow[t]{2}{*}{12.150} & \multirow[t]{2}{*}{$0.000^{* * *}$} & 0.140 & \multirow[t]{2}{*}{12.446} & \multirow[t]{2}{*}{$0.000^{* * *}$} \\
\hline & $(0.011)$ & & & $(0.011)$ & & \\
\hline \multirow[t]{2}{*}{$\mathrm{ROA}$} & -14.108 & \multirow[t]{2}{*}{-6.505} & \multirow[t]{2}{*}{$0.000^{* * *}$} & -12.071 & \multirow[t]{2}{*}{-5.899} & $0.003^{* * *}$ \\
\hline & $(2.169)$ & & & (2.046) & & \\
\hline GDPg & 5.116 & 1.600 & 0.109 & 3.637 & 1.176 & 0.240 \\
\hline & (3.198) & & & $(1.092)$ & & \\
\hline Sigma & 0.279 & 10.930 & $0.000^{* * *}$ & 0.236 & 10.398 & $0.000^{* * *}$ \\
\hline & (0.026) & & & (0.023) & & \\
\hline
\end{tabular}

Note: $\mathrm{HHI}=$ Herfindahl Hirschman index; CapRsk= capital risk; CrRsk= credit risk; LiqRSK=Liquidity Risk; OvRsk=overall risk

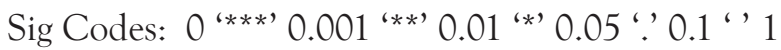

Log-Likelihood (CCR): 113 on 9 Df; (BCC) 244.52 on 9 Df

of the bank efficiency in Pakistan. The table also shows that HHI is negatively associated with average efficiency scores under the BCC model. The table further explains that capital risk, liquidity risk, and overall risk are significantly related to efficiency, while the credit risk has no significant relationship with bank efficiency in Pakistan. The control variables ROE and GDP growth also affect the bank efficiency.

\subsection{Discussion}

The efficiency scores represent a comparative ranking of banks. Our DEA-efficiency scores show that the overall private banks are at the efficient frontier, supporting the findings of (Fries \& Taci, 2005; Staikouras et al., 2008), who also concluded that 
Confidence intervals under CCR Algorithm 1

\begin{tabular}{|c|c|c|c|}
\hline & Est & pLL & \\
\hline HHI $^{* * *}$ & -6.643 & -9.525 & -4.136 \\
\hline CapR & 0.569 & -0.330 & 1.318 \\
\hline CrR & -0.305 & -1.085 & 0.295 \\
\hline LqR $^{* * *}$ & -1.733 & -2.255 & -1.150 \\
\hline OvR $^{* *}$ & -0.377 & -0.618 & -0.147 \\
\hline Size & 0.133 & 0.113 & 0.155 \\
\hline ROA $^{* * *}$ & -14.108 & -19.174 & -10.040 \\
\hline GDPg $_{\text {Sigma }}^{* * *}$ & 5.116 & -2.507 & 12.050 \\
\hline & 0.279 & 0.217 & 0.341 \\
\hline
\end{tabular}

Confidence intervals under BCC Algorithm 1

\begin{tabular}{|c|c|c|c|}
\hline & Est & pLL & pUL \\
\hline $\mathrm{HHI}^{* * *}$ & -19.531 & -29.557 & -0.177 \\
\hline CapR & 0.637 & -0.357 & 1.354 \\
\hline CrR & 0.126 & -0.672 & 0.807 \\
\hline LqR $^{* *}$ & -1.979 & -2.473 & -1.453 \\
\hline OvR & -0.261 & -0.536 & 0.030 \\
\hline Size $^{* * *}$ & 0.140 & 0.119 & 0.161 \\
\hline ROA $^{* * *}$ & -12.071 & -16.969 & -7.669 \\
\hline GDPg $^{*}$ & 3.637 & -5.324 & 11.451 \\
\hline Sigma & & 0.177 & 0.295 \\
\hline
\end{tabular}

Table 5: Regression Model (Algorithm1)

\begin{tabular}{|c|c|c|c|c|c|c|}
\hline & \multicolumn{3}{|c|}{$\mathrm{CCR}$} & \multicolumn{3}{|c|}{$\mathrm{BCC}$} \\
\hline & Coefficients & t-value & $\operatorname{Pr}(>|t|)$ & Coefficients & $\mathrm{t}$-value & $\operatorname{Pr}(>|t|)$ \\
\hline \multirow[t]{2}{*}{$\mathrm{HHI}$} & -3.953 & \multirow[t]{2}{*}{$0-9.183$} & \multirow[t]{2}{*}{$0.000 * * *$} & -4.099 & \multirow[t]{2}{*}{-10.739} & \multirow[t]{2}{*}{$0.000 * * *$} \\
\hline & $(0.430)$ & & & $(0.382)$ & & \\
\hline \multirow[t]{2}{*}{ CapRsk } & 1.108 & \multirow[t]{2}{*}{5.413} & \multirow[t]{2}{*}{$0.000 * * *$} & 1.390 & \multirow[t]{2}{*}{7.656} & \multirow[t]{2}{*}{$0.000^{* * *}$} \\
\hline & $(0.205)$ & & & $(0.182)$ & & \\
\hline \multirow[t]{2}{*}{ CrRsk } & -0.319 & \multirow[t]{2}{*}{-1.549} & \multirow[t]{2}{*}{0.121} & -0.165 & \multirow[t]{2}{*}{-0.907} & \multirow[t]{2}{*}{0.365} \\
\hline & $(0.206)$ & & & $(0.182)$ & & \\
\hline
\end{tabular}




\begin{tabular}{|c|c|c|c|c|c|c|}
\hline \multirow[t]{2}{*}{ LiqRsk } & -0.866 & \multirow[t]{2}{*}{-8.184} & \multirow[t]{2}{*}{$0.000^{* * *}$} & -0.883 & \multirow[t]{2}{*}{-9.411} & \multirow[t]{2}{*}{$0.000^{* * *}$} \\
\hline & $(0.106)$ & & & $(0.094)$ & & \\
\hline \multirow[t]{2}{*}{ OvRsk } & -0.269 & \multirow[t]{2}{*}{-4.506} & \multirow[t]{2}{*}{$0.000^{* * *}$} & -0.238 & \multirow[t]{2}{*}{-4.509} & \multirow[t]{2}{*}{$0.000^{* * *}$} \\
\hline & $(0.060)$ & & & $(0.053)$ & & \\
\hline \multirow[t]{2}{*}{ Size } & 0.170 & \multirow[t]{2}{*}{32.404} & \multirow[t]{2}{*}{$0.000 * * *$} & 0.157 & \multirow[t]{2}{*}{33.739} & \multirow[t]{2}{*}{$0.000^{* * *}$} \\
\hline & $(0.005)$ & & & $(0.005)$ & & \\
\hline \multirow[t]{2}{*}{$\mathrm{ROA}$} & -9.530 & \multirow[t]{2}{*}{-8.650} & \multirow[t]{2}{*}{$0.000 * * *$} & -8.037 & \multirow[t]{2}{*}{-8.227} & \multirow[t]{2}{*}{$0.000 * * *$} \\
\hline & $(1.102)$ & & & $(0.977)$ & & \\
\hline \multirow[t]{2}{*}{ GDPg } & 5.662 & \multirow[t]{2}{*}{3.548} & \multirow[t]{2}{*}{$0.000 * * *$} & 5.755 & \multirow[t]{2}{*}{4.067} & \multirow[t]{2}{*}{$0.000^{* * *}$} \\
\hline & $(1.596)$ & & & $(1.415)$ & & \\
\hline \multirow[t]{2}{*}{ Sigma } & 0.217 & \multirow[t]{2}{*}{20.591} & \multirow[t]{2}{*}{0.000 *** } & 0.193 & \multirow[t]{2}{*}{20.590} & \multirow[t]{2}{*}{0.000 ** } \\
\hline & $(0.011)$ & & & $(0.009)$ & & \\
\hline
\end{tabular}

Note: $\mathrm{HHI}=$ Herfindahl Hirschman index; CapRsk= capital risk; CrRsk= credit risk; LiqRSK=Liquidity Risk; OvRsk=overall risk

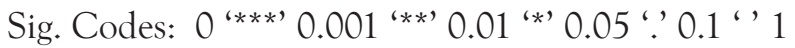

Log-Likelihood: (CCR) 22.68 on 9 Df; (BCC) 48.17 on 9 Df

Confidence intervals under CCR Algorithm 2

\begin{tabular}{|c|c|c|c|}
\hline & Est & pLL & pUL \\
\hline $\mathrm{HHI}^{* * *}$ & -3.953 & -4.737 & -3.149 \\
\hline CapR ${ }^{* * *}$ & 1.108 & 0.654 & 1.586 \\
\hline $\mathrm{CrR}$ & -0.319 & -0.802 & 0.059 \\
\hline $\mathrm{LqR}^{* * *}$ & -0.866 & -1.127 & -0.590 \\
\hline $\mathrm{OvR}^{* * *}$ & -0.269 & -0.397 & -0.153 \\
\hline Size $^{* * *}$ & 0.170 & 0.159 & 0.181 \\
\hline $\mathrm{ROA}^{* * *}$ & -9.530 & -12.795 & -7.072 \\
\hline $\mathrm{GDPg}^{* * *}$ & 5.662 & 2.273 & 9.132 \\
\hline Sigma $^{* * *}$ & 0.217 & 0.188 & 0.238 \\
\hline
\end{tabular}

Confidence intervals under BCC Algorithm 2

\begin{tabular}{|c|c|c|c|}
\hline & Est & pLL & pUL \\
\hline $\mathrm{HHI}^{* * *}$ & -4.099 & -4.815 & -3.380 \\
\hline CapR ${ }^{* * *}$ & 1.390 & 0.993 & 1.826 \\
\hline $\mathrm{CrR}$ & -0.165 & -0.590 & 0.196 \\
\hline
\end{tabular}




\begin{tabular}{|c|c|c|c|}
\hline $\mathrm{LqR}^{* * *}$ & -0.883 & -1.117 & -0.621 \\
\hline $\mathrm{OvR}^{* * *}$ & -0.238 & -0.351 & -0.133 \\
\hline $\mathrm{Size}^{* * *}$ & 0.157 & 0.159 & 0.168 \\
\hline $\mathrm{ROA}^{* * *}$ & -8.037 & 0.147 & -5.878 \\
\hline $\mathrm{GDPg}^{* * *}$ & 5.755 & 2.837 & 8.509 \\
\hline Sigma $^{* * *}$ & 0.193 & 0.168 & 0.210 \\
\hline
\end{tabular}

privately owned commercial banks (POCBs) perform better in overall efficiency than their counterparts, government-owned commercial banks (GOCBs). The efficiency scores (Table 4) represent that private banks manage their inputs very well to achieve their targets. The low efficiency of GOCBs may be attributed to the severe political intervention and low incentives to follow prudent bank management practices (Dong, Meng, Firth, \& Hou, 2014). Large banks supersede the medium and small banks in terms of efficiency. The large banks enjoy large bank networks and utilize economies of scale (Hughes \& Mester, 2013). Moreover, the conventional commercial banks are more efficient than the Islamic banks in Pakistan. Our findings suggest that the small banks in Pakistan are suffering from technical inefficiency and are less profitable as compared with large banks. Such banks need strict actions to cope with their inefficiency. This result is consistent with the result of (Moradi-Motlagh $\&$ Babacan, 2015). The truncated regression model shows that the external variables have considerable effects on the efficiency of commercial banks in Pakistan. The result for market concentration (Herfindahl-Hirschman Index) indicates a negative but significant relationship with bank efficiency in both BCC and CCR models, hence supporting the quiet life hypothesis (Hicks, 1935) where market structure is assumed to be attached to little management efforts, because firms are less risk-averse in perfect competition than in monopolistic situations. Hou et al. (2014) found the same results in the Chinese banking sector. Our findings did not justify the results of Fu and Heffernan (2009) who found no support for the quiet life hypothesis in investigating the impact of reforms on Chinese bank performance. Stiff competition in the banking sector reduces the market power of banks, which results in lowering the efficiency of banks. This provides an opportunity to devise a new viable strategy for reducing costs and gaining benefits. Zhang et al. (2013) concluded that market concentration has a negative association with efficiency in the banking sectors of BRICS countries (Brazil, Russia, India, China, and South Africa).

The results of our model show that the risk factors have a significant bearing on the efficiency of banks. Capital risk has a significant positive relationship with the efficiency in Pakistan under both CCR and BCC models. Our results agree with those of Zhang et al. (2013) and Altunbas, Carbo, Gardener, and Molyneux (2007) 
who showed a positive and significant relationship of capital risk with performance. The positive relationship shows that bank regulators and owners prefer to hold a high level of capital to total assets to maintain sound liquidity. The truncated regression gives evidence of an insignificant relationship between credit risk and the efficiency. Credit risk (non-performing loans) has always been highlighted as a negative factor affecting the efficiency of banks (Maghyereh \& Awartani, 2014). If the reserve for non-performing loans is high, this will negatively affect bank efficiency. Zhang et al. (2013) also found that credit risk has a negative association with performance and it adversely affects bank efficiency. Liquidity risk has a negative and significant relationship with the efficiency in both BCC and CCR models, indicating that banks having a lower level of loans will be more efficient than those banks with a high level of loans. Our model further explains that the overall risk is negatively associated with efficiency and is statistically significant. Zhang et al. (2013) also concluded that the overall risk in BRICs countries has a negative relationship with efficiency. Our findings clarify that banks in Pakistan usually maintain a lower level of reserves to total assets compared with banks in developed nations. The analysis also considers several control variables. The size of a bank is acknowledged as an important factor in banking studies and previous studies have reported that size has a significant relationship with the bank's efficiency (Hou et al., 2014; Pawlowska, 2016; Sufian \& Habibullah, 2011). Consistent with (Perera, Skully, \& Wickramanayake, 2007), the large banks in the current study outperformed the medium and small banks. The conventional banks and private banks are worth in efficiency. The other control variables return on assets (ROA), and GDP growth also has a significant effect on the efficiency of banks in Pakistan.

\section{Conclusion and Implications}

Bank efficiency studies are always aimed to investigate the efficiency and suggesting how bank management and regulators could take corrective actions. The current paper examined the technical efficiency of 27 commercial banks in Pakistan over the period 2007-2014, and the factors that influence their efficiency. The important aspect of our work is that it applies the double bootstrap procedure with truncated regression, as introduced by Simar and Wilson (2007), to the commercial banks in Pakistan. This is the first study that investigated the technical efficiency of commercial banks in Pakistan during and after the global banking crisis, and to do so it used the double bootstrap DEA method. Determining the efficiency scores of all the commercial banks, the paper concludes that privately-owned commercial banks (POCBs) are more efficient than their counterparts, government-owned commercial banks (GO$\mathrm{CBs})$. The private banks use their inputs more wisely to maximize their outputs and returns. Being on the efficient frontier, the large banks are more technically efficient 
than medium and small banks. The efficiency scores show that GOCBs showed just good results and the Islamic commercial banks (ICBs) have poor efficiency track. The large banks are better in efficiency than the medium and small banks. Large banks have been reported as efficient because they have more chances for diversity than small banks (Stever, 2007) and enjoy economies of scales. In the second stage, as per the hypothesized relationship (H1), the paper analyzed the effects of market concentration and risk factors on bank efficiency and the findings indicate that the market concentration has a significant negative effect on the efficiency of Pakistani banks i.e., the higher the concentration, the lower the efficiency. Similarly, in regard to the proposed hypothesis that risks have an impact on banks efficiency, the study finds that the credit risk, capital risk, and liquidity risk do matter in determining the bank efficiency. The regulators can better manage the risks while striving for achieving efficiency. The study introduces new reflections for future debate, practice, and research within the banking discourses.

\subsection{Theoretical im plications}

In terms of theory, the study presents an example of using DEA with double bootstrapping to analyze the banking sector of a developing country, thereby verifying that this sophisticated technique is useful in that and other similar contexts. The current study gives impetus to future researchers and learners to understand the performance evaluation and benchmarking of banking institutions in a comprehensive way. The study contributes to the existing literature on DEA studies by examining a new context. The study also enriches the banking literature by comparing the types of banks and ascertaining the factors that affect their efficiencies. In particular, the study compared the efficiency of Islamic commercial banks with conventional commercial banks that are emerging in the Islamic world and may inspire future studies to do a more in-depth evaluation of the Islamic banking model. The findings can be entirely or partially important for future studies in analyzing efficiencies of banks or other decision-making units (DMUs). Theoretically, the study enriches the existing literature on banking with new insights in terms of the comprehensive methodology because the DEA double bootstrapping procedure allows researchers to evaluate the impact of contextual variables on the performance of different types of DMUs. This will further lead towards consideration of DEA with two-stage double bootstrapping in various feasible contexts.

\subsection{Practical implications}

The study is rich in terms of industrial and managerial applications, as it not only provides comparison but also investigates the effect of market concentration and risk factors on the performance of the banking industry. The findings have implications 
for the bank owners, regulators, and government. The government-owned commercial banks (GOCBs) must plan to upgrade their efficiency and provide better services to the general public. The GOCBs require more emphasis on their operations and development. The State Bank of Pakistan should strictly observe the practices and procedure of GOCBs to make them more efficient as GOCBs represent the public and government interests. The privately owned banks, although performing well, still need efforts to maintain and upgrade their efficiency. Our results indicate that the Islamic banks in Pakistan were underperforming during the study period, which means their management must concentrate on gaining efficiency. The initiative of the State Bank of Pakistan to improve the working of Islamic Banks is crucial for their future growth, which requires policies that are feasible for the bank. The growth of Islamic banking can be ensured by enlarging their products and relaxing their policies. The liquidity risk that is usually generated from non-performing loans can be reduced if political and legal procedures are observed in their true spirits. The study is helpful for decision making by individual bank customers, bank management, and regulators to understand the dynamics of efficiency and know key factors affecting bank performance.

\section{Limitations and Future Research}

Although the study contributes to our understanding of market concentration, risk factors, and the efficiency of banks, yet the authors acknowledge several limitations. The first limitation of the study is the issue of generalizability. The study was conducted in a developing country (Pakistan), so its results can be generalized to the same settings of developing countries but it is inappropriate to generalize to developed countries. The implications should be understood in the similar contexts and environment. The second limitation is related to the data. The study uses annual bank data for analyzing the efficiencies, which may not be as informative as the banks' quarterly or monthly data. Using the monthly or quarterly data will be interesting in future studies. Thirdly, our analysis excluded foreign banks due to data constraints and specialized banks due to the specialized nature of their operations. The specialized banks focus on promoting their specific realms, therefore, it was difficult to evaluate their efficiency in comparison with commercial banks. The specialized banks need separate attention from future researchers. The foreign banks can also be worth investigating to examine their efficiency and the factors that affect their efficiency. Future study may consider the number of bank branches or the number of years since the bank's establishment as external variables. Study of the regulatory framework is another worthwhile pursuit in the context of bank efficiency. Multi-cultural aspects in the determinants of bank efficiency and international comparisons are also appealing for future studies. The legal framework of the country and international regulations 
like the Basel agreements can also be interesting research topics for future studies. Similarly, investigating the government support and bank efficiency can be a good topic for future research. The current study mainly relied on the quantitative design of data but the qualitative aspects are also worth pursuing to understand the managerial and regulatory aspects.

\section{References}

Abbasoğlu, O. F., Aysan, A. F., \& Gunes, A. (2007). Concentration, competition, efficiency and profitability of the Turkish banking sector in the post-crises period. Retrieved from https://mpra.ub.uni-muenchen. de/5494/1/MPRA_paper_5494.pdf

Aebi, V., Sabato, G., \& Schmid, M. (2012). Risk management, corporate governance, and bank performance in the financial crisis. Journal of Banking $\mathbb{E}$ Finance, 36(12), 3213-3226.

Aftab, M., Ahamad, S., Ullah, W., \& Sheikh, R. A. (2011). The impact of bank efficiency on share performance: Evidence from Pakistan. African Journal of Business Management, 5(10), 3975-3980.

Ahmad, S., \& Rahim Abdul Rahman, A. (2012). The efficiency of Islamic and conventional commercial banks in Malaysia. International Journal of Islamic and Middle Eastern Finance and Management, 5(3), 241-263.

Alexander, W. R. J., Haug, A. A., \& Jaforullah, M. (2010). A two-stage double-bootstrap data envelopment analysis of efficiency differences of New Zealand secondary schools. Journal of Productivity Analysis, 34(2), 99-110.

Altunbas, Y., Carbo, S., Gardener, E. P., \& Molyneux, P. (2007). Examining the relationships between capital, risk and efficiency in European banking. European Financial Management, 13(1), 49-70.

Altunbas, Y., Liu, M.-H., Molyneux, P., \& Seth, R. (2000). Efficiency and risk in Japanese banking. Journal of Banking Ë Finance, 24(10), 1605-1628.

Ariss, R. T. (2010). On the implications of market power in banking: Evidence from developing countries. Journal of Banking Eु Finance, 34(4), 765-775.

Bain, J. S. (1956). Barriers to new competition: their character and consequences in manufacturing industries (Vol. 329): Harvard University Press Cambridge, MA.

Banker, R. D., \& Natarajan, R. (2008). Evaluating contextual variables affecting productivity using data envelopment analysis. Operations Research, 56(1), 48-58.

Banker, R. D., Charnes, A., \& Cooper, W. W. (1984). Some models for estimating technical and scale inefficiencies in data envelopment analysis. Management Science, 30(9), 1078-1092.

Banya, R., \& Biekpe, N. (2018). Banking Efficiency and its determinants in selected Frontier African Markets. Economic Change and Restructuring, 51(1), 69-95. 
Barros, C. P., Caporale, G. M., \& Abreu, M. (2008). Productivity drivers in European banking: Country effects, legal tradition and market dynamics. Centre for International Capital Markets Discussion Papers, 7, 1-26

Beccalli, E., Casu, B., \& Girardone, C. (2006). Efficiency and stock performance in European banking. Journal of Business Finance $\mathcal{E}$ Accounting, 33(1-2), 245-262.

Berger, A. N., \& Hannan, T. H. (1998). The efficiency cost of market power in the banking industry: A test of the "quiet life" and related hypotheses. Review of Economics and Statistics, 80(3), 454-465.

Berger, A. N., Hasan, I., \& Zhou, M. (2009). Bank ownership and efficiency in China: What will happen in the world's largest nation? Journal of Banking $\mathcal{E}$ Finance, 33(1), 113-130.

Berger, A. N., \& Humphrey, D. B. (1997). Efficiency of financial institutions: International survey and directions for future research. European Journal of Operational Research, 98(2), 175-212.

Berger, A. N., \& Mester, L. J. (1997). Inside the black box: What explains differences in the efficiencies of financial institutions? Journal of Banking $\mathcal{E}$ Finance, 21(7), 895-947.

Bonin, J. P., Hasan, I., \& Wachtel, P. (2005). Bank performance, efficiency and ownership in transition countries. Journal of Banking $\mathcal{E}$ Finance, 29(1), 31-53.

Brandao-Marques, L., Correa, R., \& Sapriza, H. (2018). Government support, regulation, and risk taking in the banking sector. Journal of Banking $\mathcal{E}$ Finance.

Bremus, F. M. (2015). Cross-border banking, bank market structures and market power: Theory and cross-country evidence. Journal of Banking \& Finance, 50, 242-259.

Brozen, Y., \& Bittlingmayer, G. (1982). Concentration, mergers, and public policy: Free Press.

Brunnermeier, M. K. (2008). Deciphering the liquidity and credit crunch 2007-08. National Bureau of Economic Research.

Burki, A. A., \& Niazi, G. (2010). Impact of financial reforms on efficiency of state-owned, private and foreign banks in Pakistan. Applied Economics, 42(24), 3147-3160.

Chang, C.-C. (1999). The nonparametric risk-adjusted efficiency measurement: An application to Taiwan's major rural financial intermediaries. American Journal of Agricultural Economics, 81(4), 902-913.

Charnes, A., Cooper, W. W., \& Rhodes, E. (1978). Measuring the efficiency of decision-making units. European Journal of Operational Research, 2(6), 429-444.

Cook, W. D., Tone, K., \& Zhu, J. (2014). Data envelopment analysis: Prior to choosing a model. Omega, $44,1-4$

Davidova, S., \& Latruffe, L. (2007). Relationships between technical efficiency and financial management for Czech Republic farms. Journal of Agricultural Economics, 58(2), 269-288.

De Haan, J., \& Poghosyan, T. (2012). Bank size, market concentration, and bank earnings volatility in 
the US. Journal of International Financial Markets, Institutions and Money, 22(1), 35-54.

Demsetz, H. (1973). The Market concentration doctrine: An examination of evidence and a discussion of policy (Vol. 7): Washington: American Enterprise Institute for Public Policy Research.

Despotis, D. (2005). Measuring human development via data envelopment analysis: The case of Asia and the Pacific. Omega, 33(5), 385-390.

Dong, Y., Meng, C., Firth, M., \& Hou, W. (2014). Ownership structure and risk-taking: Comparative evidence from private and state-controlled banks in China. International Review of Financial Analysis, $36,120-130$.

Fiordelisi, F., Marques-Ibanez, D., \& Molyneux, P. (2011). Efficiency and risk in European banking. Journal of Banking $\mathcal{E}$ Finance, 35(5), 1315-1326.

Fries, S., \& Taci, A. (2005). Cost efficiency of banks in transition: Evidence from 289 banks in 15 post-communist countries. Journal of Banking $\mathcal{E}$ Finance, 29(1), 55-81.

Fu, X. M., \& Heffernan, S. (2009). The effects of reform on China's bank structure and performance. Journal of Banking $\mathcal{E}$ Finance, 33(1), 39-52.

Ghosh, S. (2015). Political transition and bank performance: How important was the Arab Spring? Journal of Comparative Economics. 44(2), 372-382.

Haq, M., \& Heaney, R. (2012). Factors determining European bank risk. Journal of International Financial Markets, Institutions and Money, 22(4), 696-718.

Haque, A., \& Tariq, A. (2012). Efficiency of banks in Pakistan: A non parametric approach. Business and Economic Research, 2(1).

Hasan, M. M., \& Dridi, J. (2010). The effects of the global crisis on Islamic and conventional banks: A comparative study. IMF Working Papers, 1-46.

Hicks, J. R. (1935). Annual survey of economic theory: The theory of monopoly. Econometrica: Journal of the Econometric Society, 1-20.

Hou, X., Wang, Q., \& Zhang, Q. (2014). Market structure, risk taking, and the efficiency of Chinese commercial banks. Emerging Markets Review, 20, 75-88. doi: 10.1016/j.ememar.2014.06.001

Huang, T.-H., Chiang, D.-L., \& Tsai, C.-M. (2015). Applying the New Metafrontier Directional Distance Function to Compare Banking Efficiencies in Central and Eastern European Countries. Economic Modelling, 44, 188-199.

Hughes, J. P., \& Mester, L. J. (2013). Who said large banks don't experience scale economies? Evidence from a risk-return-driven cost function. Journal of Financial Intermediation, 22(4), 559-585.

Iannotta, G., Nocera, G., \& Sironi, A. (2007). Ownership structure, risk and performance in the European banking industry. Journal of Banking $\mathcal{E}$ Finance, 31(7), 2127-2149. 
Iqbal, M., \& Molyneux, P. (2005). Thirty years of Islamic banking: history, performance, and prospects.

Jebali, E., Essid, H., \& Khraief, N. (2017). The analysis of energy efficiency of the Mediterranean countries: A two-stage double bootstrap DEA approach. Energy, 134, 991-1000.

Kauko, K. (2009). Managers and efficiency in banking. Journal of Banking $\mathcal{G}$ Finance, 33(3), 546-556.

Khan, F. U. (2014). Technical efficiency of domestic commercial banks: A case study of Pakistan. European Journal of Business and Management, 6(37), 321-330.

Khan, M. Z. (2009). Liberalization and economic crisis in Pakistan. Retreived from https://aric.adb.org/pdf/ aem/external/financial_market/Pakistan/pak_mac.pdf.

Kumbhakar, S. C., \& Wang, D. (2007). Economic reforms, efficiency and productivity in Chinese banking. Journal of Regulatory Economics, 32(2), 105-129.

Laeven, L., \& Levine, R. (2009). Bank governance, regulation and risk taking. Journal of financial economics, 93(2), 259-275.

Lensink, R., Meesters, A., \& Naaborg, I. (2008). Bank efficiency and foreign ownership: Do good institutions matter? Journal of Banking $\mathcal{E}$ Finance, 32(5), 834-844.

Li, L.-b., Liu, B.-1., Liu, W.-1., \& Chiu, Y.-H. (2017). Efficiency evaluation of the regional high-tech industry in China: A new framework based on meta-frontier dynamic DEA analysis. Socio-Economic Planning Sciences, 60, 24-33.

Lin, Y.-H., Hsu, G. J., \& Hsiao, C.-K. (2007). Measuring efficiency of domestic banks in Taiwan: application of data envelopment analysis and Malmquist index. Applied economics letters, 14(11), 821-827.

Lu, C.-C., Chiu, Y.-H., Shyu, M.-K., \& Lee, J.-H. (2013). Measuring CO 2 emission efficiency in OECD countries: application of the hybrid efficiency model. Economic Modelling, 32, 130-135.

Luo, D., Yao, S., Chen, J., \& Wang, J. (2011). World financial crisis and efficiency of Chinese commercial banks. The World Economy, 34(5), 805-825.

Maghyereh, A. I., \& Awartani, B. (2014). The effect of market structure, regulation, and risk on banks efficiency: Evidence from the Gulf cooperation council countries. Journal of Economic Studies, 41(3), 405-430.

Masudul Alam Choudhury, P., Abbas, M., Hammad, R. S., Elshahat, M. F., \& Azid, T. (2015). Efficiency, productivity and Islamic banks: An application of DEA and Malmquist index. Humanomics, 31(1), 118-131.

Matousek, R., Rughoo, A., Sarantis, N., \& Assaf, A. G. (2015). Bank performance and convergence during the financial crisis: Evidence from the 'old'European Union and Eurozone. Journal of Banking $\mathcal{E}$ Finance, 52, 208-216.

Mirzaei, A., Moore, T., \& Liu, G. (2013). Does market structure matter on banks' profitability and 
stability? Emerging vs. advanced economies. Journal of Banking $\mathcal{E}$ Finance, 37(8), 2920-2937.

Mohsni, S., \& Otchere, I. (2014). Risk taking behavior of privatized banks. Journal of Corporate Finance, 29, 122-142.

Mokhtar, H. S. A., Abdullah, N., \& Alhabshi, S. M. (2008). Efficiency and competition of Islamic banking in Malaysia. Humanomics, 24(1), 28-48.

Moradi-Motlagh, A., \& Babacan, A. (2015). The impact of the global financial crisis on the efficiency of Australian banks. Economic Modelling, 46, 397-406.

Nguyen, M., Skully, M., \& Perera, S. (2012). Market power, revenue diversification and bank stability: Evidence from selected South Asian countries. Journal of International Financial Markets, Institutions and Money, 22(4), 897-912. doi: 10.1016/j.intfin.2012.05.008

Odeck, J. (2007). Measuring technical efficiency and productivity growth: a comparison of SFA and DEA on Norwegian grain production data. Applied Economics, 39(20), 2617-2630.

Pan, C.-M. (2005). Market structure and profitability in the international tourist hotel industry. Tourism Management, 26(6), 845-850.

Panayides, P. M., Maxoulis, C. N., Wang, T. F., \& Ng, K. Y. A. (2009). A critical analysis of DEA applications to seaport economic efficiency measurement. Transport Reviews, 29(2), 183-206.

Paradi, J. C., Yang, Z., \& Zhu, H. (2011). Assessing bank and bank branch performance Handbook on data envelopment analysis (pp. 315-361): Springer.

Pawlowska, M. (2016). Does the size and market structure of the banking sector have an effect on the financial stability of the European Union? The Journal of Economic Asymmetries.

Perera, S., Skully, M., \& Wickramanayake, J. (2007). Cost efficiency in South Asian banking: the impact of bank size, state ownership and stock exchange listings. International Review of Finance, 7(1102), 35-60.

Rosman, R., Wahab, N. A., \& Zainol, Z. (2014). Efficiency of Islamic banks during the financial crisis: An analysis of Middle Eastern and Asian countries. Pacific-Basin Finance Journal, 28, 76-90.

Saeed, F. A., \& Baber Adeeb, M. H. (2013). Examining Efficiency of Islamic and Conventional Banks in Pakistan: Using Data Envelopment Analysis. Global Journal of Management And Business Research, 13(10), 25-34.

Sathye, S., \& Sathye, M. (2017). Do ATMs Increase Technical Efficiency of Banks in a Developing Country? Evidence from Indian Banks. Australian Accounting Review, 27(1), 101-111.

Shafique, O., Hussain, N., \& Taimoor Hassan, M. (2013). Differences in the risk management practices of Islamic versus conventional financial institutions in Pakistan: An empirical study. The Journal of Risk Finance, 14(2), 179-196.

Shakil Ahmad, M., Rashid, S., \& Ehtisham-Ul-Mujeeb. (2012). ECRM and customers: a case of Askari 
Commercial Bank, Pakistan. Business Strategy Series, 13(6), 323-330.

Shepherd, W. G. (1983). Economies of scale and monopoly profits Industrial organization, antitrust, and public policy (pp. 165-204): Springer.

Silva, T. C., Tabak, B. M., Cajueiro, D. O., \& Dias, M. V. B. (2017). A comparison of DEA and SFA using micro-and macro-level perspectives: Efficiency of Chinese local banks. Physica A: Statistical Mechanics and its Applications, 469, 216-223.

Simar, L., \& Wilson, P. W. (2007). Estimation and inference in two-stage, semi-parametric models of production processes. Journal of econometrics, 136(1), 31-64.

Soedarmono, W., Machrouh, F., \& Tarazi, A. (2013). Bank competition, crisis and risk taking: Evidence from emerging markets in Asia. Journal of International Financial Markets, Institutions and Money, 23, 196-221. doi: 10.1016/j.intfin.2012.09.009

Staikouras, C., Mamatzakis, E., \& Koutsomanoli-Filippaki, A. (2008). Cost efficiency of the banking industry in the South Eastern European region. Journal of International Financial Markets, Institutions and Money, 18(5), 483-497.

Stever, R. (2007). Bank size, credit and the sources of bank market risk. BIS Working Paper No. 238.

Stewart, C., Matousek, R., \& Nguyen, T. N. (2016). Efficiency in the Vietnamese banking system: A DEA double bootstrap approach. Research in International Business and Finance, 36, 96-111.

Sufian, F. (2009). Determinants of bank efficiency during unstable macroeconomic environment: Empirical evidence from Malaysia. Research in International Business and Finance, 23(1), 54-77.

Sufian, F., \& Habibullah, M. S. (2011). Opening the black box on bank efficiency in China: does economic freedom matter? Global Economic Review, 40(3), 269-298.

Sun, L., \& Chang, T.-P. (2011). A comprehensive analysis of the effects of risk measures on bank efficiency: Evidence from emerging Asian countries. Journal of Banking $\mathcal{E}$ Finance, 35(7), 1727-1735. doi: $10.1016 /$ j.jbankfin.2010.11.017

Usmani, M. I. A., \& Zubairi, Z. (2002). Islamic banking. Karachi: Darul-Ishaat Urdu Bazar.

Wanke, P., Azad, M. A. K., \& Barros, C. (2016). Efficiency factors in OECD banks: A ten-year analysis. Expert Systems with Applications, 64, 208-227.

Wanke, P., Barros, C., \& Emrouznejad, A. (2016). Assessing productive efficiency of banks using integrated Fuzzy-DEA and bootstrapping: A case of Mozambican banks. European Journal of operational research, 249(1), 378-389.

Wijesiri, M., Viganò, L., \& Meoli, M. (2015). Efficiency of microfinance institutions in Sri Lanka: a two-stage double bootstrap DEA approach. Economic Modelling, 47, 74-83.

Worthington, A. C. (2004). Determinants of merger and acquisition activity in Australian cooperative 
deposit-taking institutions. Journal of business research, 57(1), 47-57.

Yang, C., \& Liu, H.-M. (2012). Managerial efficiency in Taiwan bank branches: A network DEA. Economic Modelling, 29(2), 450-461.

Yao, S., Han, Z., \& Feng, G. (2008). Ownership reform, foreign competition and efficiency of chinese commercial banks: A non-parametric approach. The World Economy, 31(10), 1310-1326.

Ye, Q., Xu, Z., \& Fang, D. (2012). Market structure, performance, and efficiency of the Chinese banking sector. Economic Change and Restructuring, 45(4), 337-358.

Zhang, J., Jiang, C., Qu, B., \& Wang, P. (2013). Market concentration, risk-taking, and bank performance: Evidence from emerging economies. International Review of Financial Analysis, 30, 149-157. doi: $10.1016 /$ j.irfa.2013.07.016

Zhang, N. J., Unruh, L., \& Wan, T. T. (2008). Has the Medicare prospective payment system led to increased nursing home efficiency? Health Services Research, 43(3), 1043-1061. 
